\title{
Integration of Legalization Information System Web-Based using Shipping API and Telegram API
}

\author{
Sucipto Sucipto ${ }^{1}$, Jamilah Karaman ${ }^{2}$ \\ ${ }^{1}$ Information System Universitas Nusantara PGRI Kediri, ${ }^{2}$ Computer Science Universitas Muhammadiyah \\ Ponorogo \\ ${ }^{1}$ sucipto@unpkediri.ac.id \\ ${ }^{2}$ milafergie.mfegmail.com
}

\begin{abstract}
Education is a right for every citizen. Quality education makes people more intelligent. Educational outcomes documented in a file called a diploma. A diploma is a necessary file for doing things related to work or other administrative matters. Generally, the diploma file submitted is in the form of a photocopy of a certificate that has been legalized for administrative requirements. The process of legalizing diplomas is often a hindrance because the time required is quite long and especially if someone is in an area far from where to take care of legalization. In the industrial era 4.0, information technology can be utilized to facilitate public access to services in the world of education, for example, using technology to implement an online legalization system. Application of technology in the legalization process is not just online but can be integrated with API (Application Programming Interface). It can attract millennial access to the application easily. There are two APIs used, namely the Shipping API and the Social Messaging API. Shipping API makes it easy to check shipping costs based on alumni location. Social messaging API with assistant features so that it can be easier to serve alumni accessing application features via Telegram. This study aims to facilitate the alumni in legalizing online to make timeefficient and affordable-implementation of information systems with the integrated website media Telegram API and Rajaongkir or shipping cost API. Based on testing, the usability testing results obtained a value of 4.56 on a scale of 5. These results indicate that the application can function following the needs of users of information systems.
\end{abstract}

Keywords: legalization, API, social messaging, telegram, web-base

\section{INTRODUCTION}

One of the goals of the Indonesian people is to educate the nation's life. Objectives set out to educate the country on the opening of the fourth paragraph of the Constitution of the Republic of Indonesia Year 1945 [1]. One of the concrete efforts taken to educate the nation's life is to optimize teaching and learning activities in the world of education. The essence of the educational process that reached all the future generations is to foster the potential of religious or spiritual strength, self-control, personality, intelligence, noble character, and skills needed by him, society, nation and state [2]. The output form of the result of learning while studying is proof of graduates who are called diplomas.

Everyone needs to legalize a diploma in completing the requirements to continue their education to a higher level, apply for a job, apply for prospective civil servants, make a passport, or other needs. A legalization is a non-standard form of the word legalization. Authorize the meaning of legalization required by law or statute. Legalizing documents is a way to validate copies of documents. The legalization of documents is carried out on relevant documents that are copied and then authorized by the agency with a signature accompanied by the full name and stamp of the agency.

The procedure for Legalizing is quite easy, namely by making a photocopy of the diploma file and then being asked to legalize it to the academy or to the authorities to carry out the legalization of the diploma. This study discusses the existing online legalization system of an academy in Kediri rooting from problems that arise if the diploma holders reside far from their original studies and even differ from cities and countries. In the first data collection, it was found that most of the alumni at one of the $\mathrm{X}$ academy continued their education to tertiary institutions. The problem occurs when an institution/college alumni are outside the Kediri region; then, alumni should come to the academy to ask for legalized diploma takes time.

This research uses an API (Application Programming Interface) to optimize information systems. API is a language and message format utilized by application programs to communicate with operating systems or other control programs such as database management systems (DBMS) or communication protocols. API is an interface that is used to access 
applications or services from a program. The API allows developers to use functions that already exist from other applications, so there is no need to rebuild from the first step [3]. API illustration is in Fig. 1.

Several studies on the topics discussed in this study include Research with Media Integration Postage API conducted by Stefanus Ericko Surya in 2015 with the title Design and manufacture of excellent motorbike ecommerce websites. This study discusses motorcycle sales through e-commerce with the integration of the Postage API. Users can accept the results of this study information system with API shipping cost with satisfaction results of $76.5 \%$ [4].

Research on the topic of the telegram was carried out by Raga Nufusula in 2018 with the title design chatbot on pulse servers using the telegram bot API. This study discusses the integration of the pulse server with the telegraph social messaging API. The results of this research API can make an introduction to users who have registered as agents and other commands relating to credit transactions. Based on the test results, the telegram bot has run according to the design. Telegram bot that is made can be used as an alternative medium in conducting credit transactions [5].

Kurnia Fitri researched the topic of the legalized information system web in 2018 with the title design of a web-based document legalization information system at the Faculty of Engineering, Padang State University. This study discusses the online legalization system. The system built only uses a web-based platform. The results of this study users can legalize online and monitor the status of legalization [6].

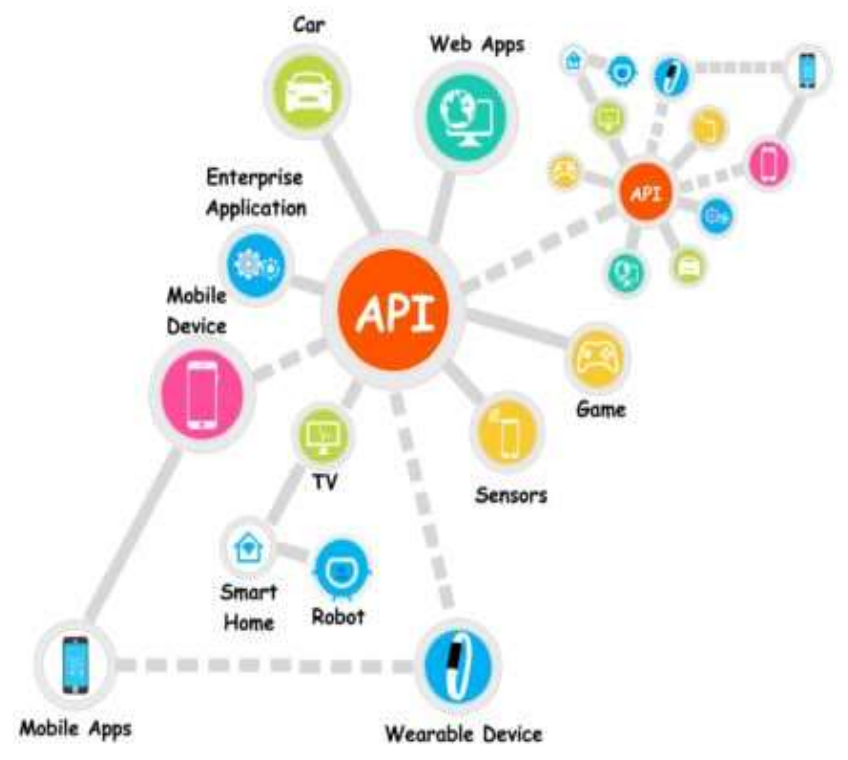

Fig. 1 API
The research that will be carried out combines some of the research previously discussed, namely, by creating a web-based online legalization application with the integration of the social messaging API and the shipping cost API. Application features are built to facilitate alumni in terms of accessing various web platforms and social messaging. The application created can describe the transparency of the legalization process. Alumni can find out the cost and status of submission through the web and social messaging platform.

Optimization features on the application of the system legalized online with the integration of API (Application Programming Interface). The API used is the social messaging API that is used for registration features and some other information. The social messaging API feature was chosen because many millennial generations use social messaging, namely, telegram [7][8]. Another feature is the Shipping Cost API, which is used to calculate shipping costs according to alumni location. The application platform consists of web-based and social messaging platforms.

The social messaging-based online legalization system aims to make it easier for alumni to legalize their relevant documents quickly-the facilities provided by authorizing from a distance outside Kediri. Ease of access must be applied because it follows the industrial era 4.0 [9]. Industry 4.0 optimizes access electronically that must be carried out for the comfort and smoothness of bureaucratic system services in educational institutions [10]. The system built is not only limited to online legalization but also integration with social messaging to facilitate alumni access to the legalized system. The benefits that can be given include making the legalization system faster and more comfortable and transparent services. The legalization process can be monitored using a web application or a social messaging application. The system provided facilitates alumni in saving time and money to legalize to increase productivity with administrative matters that require a considerable amount of time.

\section{METHOD}

Action research is research that focuses directly on the application of social action that can be both qualitative and quantitative [11]. This study uses the action research method, as outlined in the waterfall model. The Action Research Method is shown in Fig. 2.

Action research methods are distributed into the waterfall model. The Reflect stage represents "Communication," the Plan represents "Planning," the Act represents "modeling and construction," and the 
observer represents "the deployment.". The waterfall model is a method of developing information systems that are systematic and sequential [12]. This model is included in the generic model in software engineering, and Winston Royce introduced it firstly. This model is the most widely used in Software Engineering. This model is called the waterfall because step by step must wait for the completion of the previous stage and proceed sequentially [13]. The flow of the waterfall model is in Fig. 3.

The Communication stage is carried out before starting technical work. At this stage, the researcher explores the information needed to build an online legalized information system. The object of research chosen was a secondary academy in Kediri. The data required is in the form of academy experience data, especially those directly related to the legalization process, including the administration section and counseling guidance teacher. Researchers also took data from alumni who were in one city or outside the city. Data collected helps define software features and functions. Additional data collection can also be taken from scientific journal references, articles, and the internet. The next stage is the planning stage; the researcher explains the estimation of the technical tasks that will be carried out by the research members and the team. This stage also takes into account the risks that can occur, the resources needed to make the system, the work products to be produced, the scheduling of work to be carried out, and tracking the process of working the system

The next stage is the Modeling and Construction stage. This stage is a system stage that focuses on designing data structures, software architecture, display interfaces, and program algorithms. The aim is to better understand the big picture of what will be done. The deployment stage is the stage of implementing the software to the user, namely the academy. At this stage, the researcher will test the system based on usability testing. Software development is based on feedback from users so that the operation can continue to run and develop according to its function [13]. Schematic diagram of legalized information system is as shown in Fig. 4.

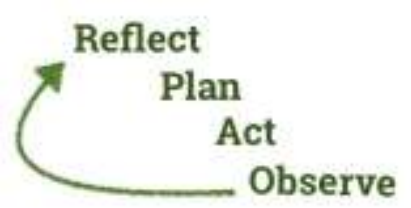

Fig. 2 Action research

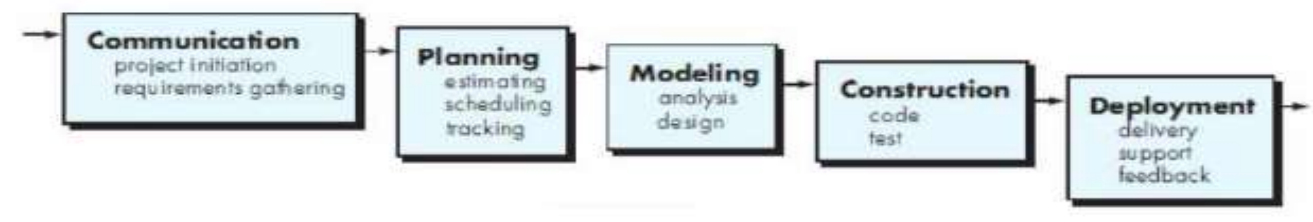

Fig. 3 Waterfall model

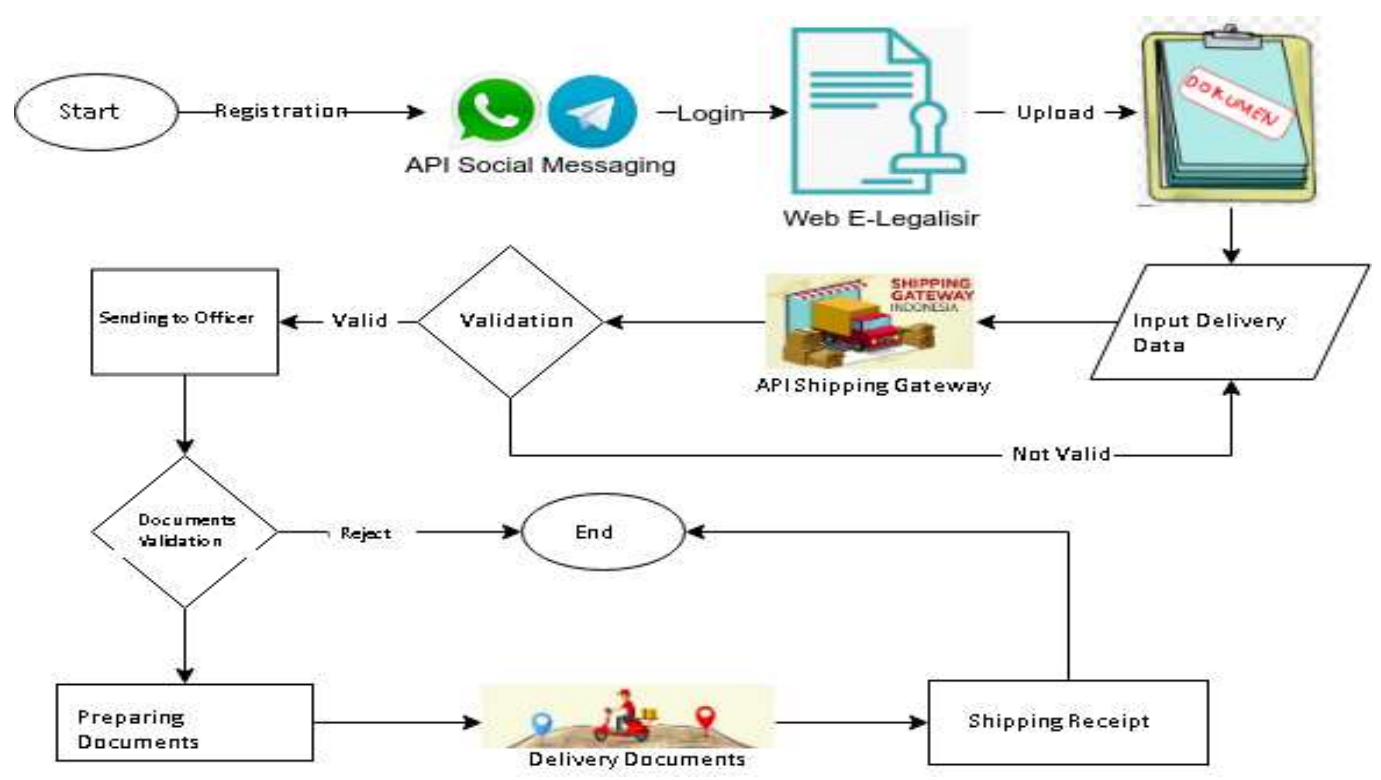

Fig. 4 E-legalized system based online social messaging 
The system flow in Fig. 4 starts from the alumni registering through a telegraph social messaging bot. In addition to registering for social messaging bots, alumni can also find out users and passwords, check the status of legalized transactions, and find out the latest information from the academy. The step after registering is $\log$ in to the E-Legalized system to upload documents and fill out forms. After completing the alumni form, enter the delivery destination integrated with the Shipping Cost API. Then the alumni fill out and validate the data; the academy will get a notification via the social messaging API and then will validate the legalized file to process the data. After the data is following the academy legalization, then the academy send the legalized physical file to the alumni address. The academy enter the receipt address. Alumni can find out the file processing notification via social messaging.

\section{RESULT AND DISCUSSION}

The Waterfall model conducted this research. This model uses a systematic and sequential approach to software development that starts at the system level and develops through analysis, design, coding, and testing [14]. This research model is illustrated in Fig. 3. The illustration of the Waterfall method can be modified according to the research needs [15].

The steps taken are Communications and Planning by taking data on several research objects in SMA / SMK Kediri. At the communications stage, the data displayed diagrammatically are found using the Flow diagram. The stages of making diagram designs are part of the Modeling stage. The design stage consists of two steps, namely the main diagram design, namely level 0 diagram and web-based interface design using Object Oriented native PHP programming. The main diagram design using Data Flow Diagrams (DFD) will explain the flow system that will be built. DFD Level 0 design drawings show in Fig. 4.

In the system built, there are two main entities, namely users and operators. Users on the network developed represent alumni entities. Operators in the system built to serve the object of the agency that carries out the task of online legalization system management. There is one new entity, the telegram BOT entity. Telegram bot entities help the functions of the two main entities namely user entities and operator entities.

The DFD system design scheme level 0 in Fig. 5 shows the basic system flow of online legalization. In Fig. 4, there is a business process for each entity. In the User Entity, there are ten business processes, in the Operator entity, there are nine business processes, and in the bot entity, there are four business processes. User entities can register independently, login, find out various information, fill out legalized forms, send messages, update passwords, upload legalized files, update payment data, and legalizing shipping.

There are several business entity operator processes, including user data management, logging in, providing information to users, viewing legalized data statistics, updating passwords, sending messages, verifying legalization, and legalizing data management. Telegram bot entities serve as servants for users and operators. The tasks performed by the bot are for the registration, notification to users and operators, and legalization verification. Bots ease the burden on users and operators. Telegram bot offers as an alternative search interface with integrated full-text services [16], [17]. The instant messaging service that is implemented integrates the notification system on smartphone devices, as well as the telephone call system and short message service (SMS). Bot devices can improve communication between users [18].

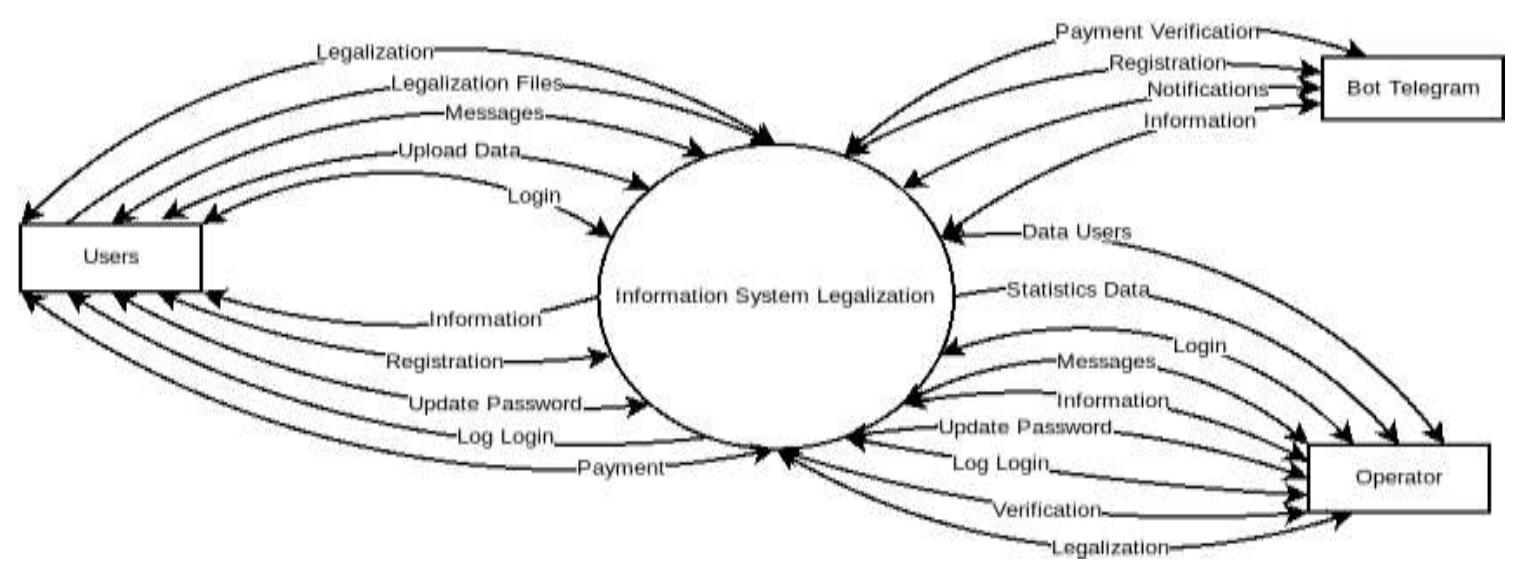

Fig. 5 DFD level 0 
Fig. 6 is a database relations design in information systems. The database uses a DBMS (Database Management System) design. DBMS has the advantage of being one of the system constraints that protect data integration between tables [19], [20] Design Database design is under DFD derivatives. There are six connected tables. The database table design in Fig. 6 uses the MariaDB database with the InnoDB engine. InnoDB engine functions as a database relation [21].

The design phase of implementing the information system interface is legalized using a bootstrap framework with the adminLTE template. The system login design is in Fig. 7. On the system, login interface the user can $\log$ in by entering a username and password. Users can register using two methods, namely via bot telegram or web-base.

The code phase is part of the construction phase. This stage uses sublime text version 3 tools. Sublime Text is a text editor used in making legalized information systems, namely web programming languages and database programming. The code structure of the legalized information system consists of two main modules, namely the admin module and the user module, the two modules represent the functions of the primary entity, namely the user and operator. The two main modules consist of various modules that are connected. On the system, there is also an external module, which is a module that consists of CSS modules, namely jQuery, bootstrap, awesome and ionic fonts. Program modules include PDF, Excel, and server-side data table modules

The dashboard on the legalized information system is divided into two entities, namely users and operators, interfaces in the form of a web-based. The dashboard design is as shown in Fig. 8. The difference between dashboard users and operators lies in the menu permissions. Menu permissions such as modules defined in DFD Fig. 4.

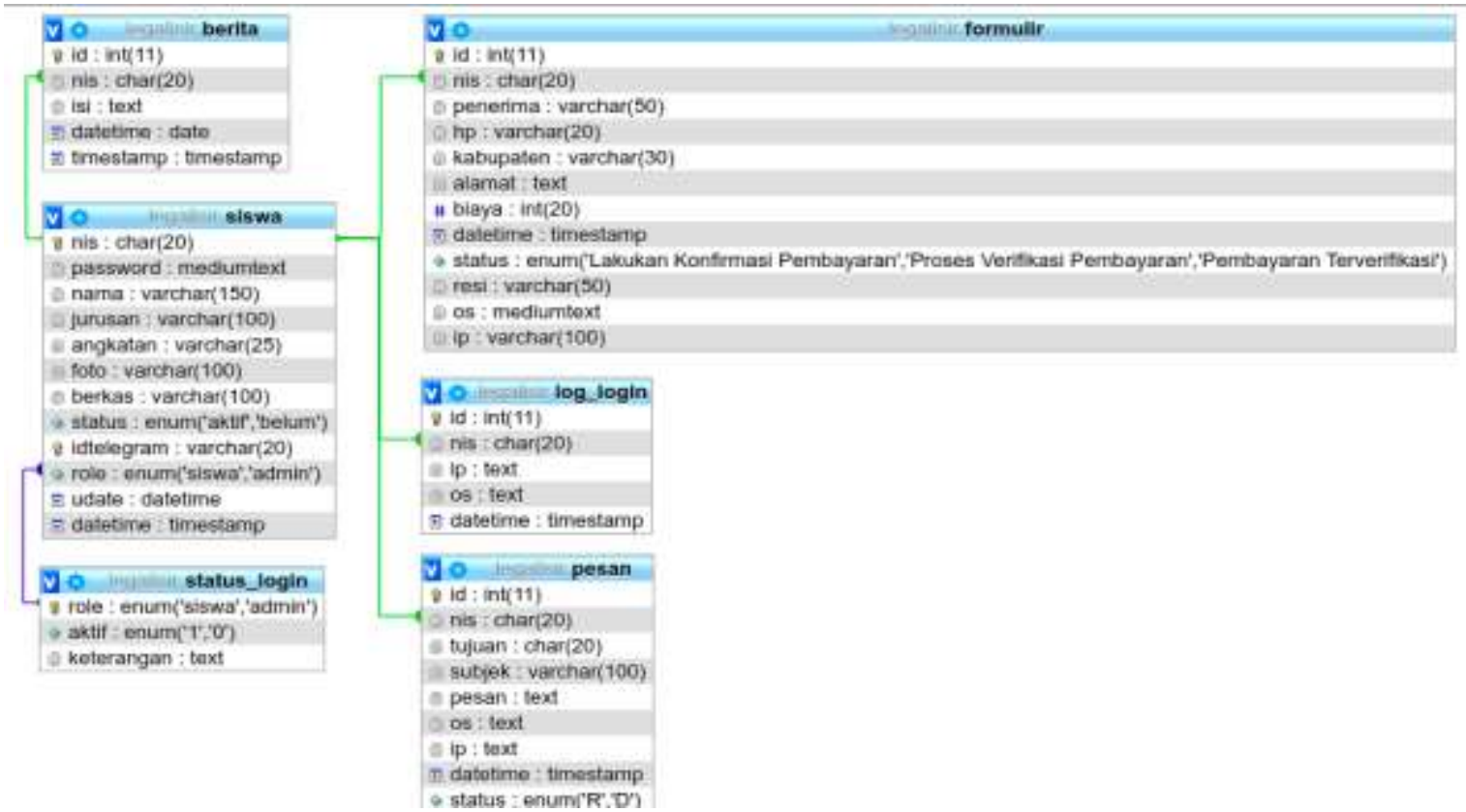

Fig. 6 Database system legalization

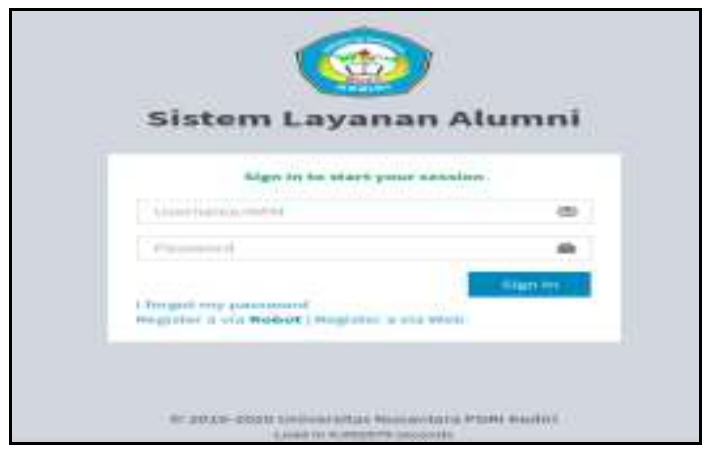

Fig. 7 Login system 


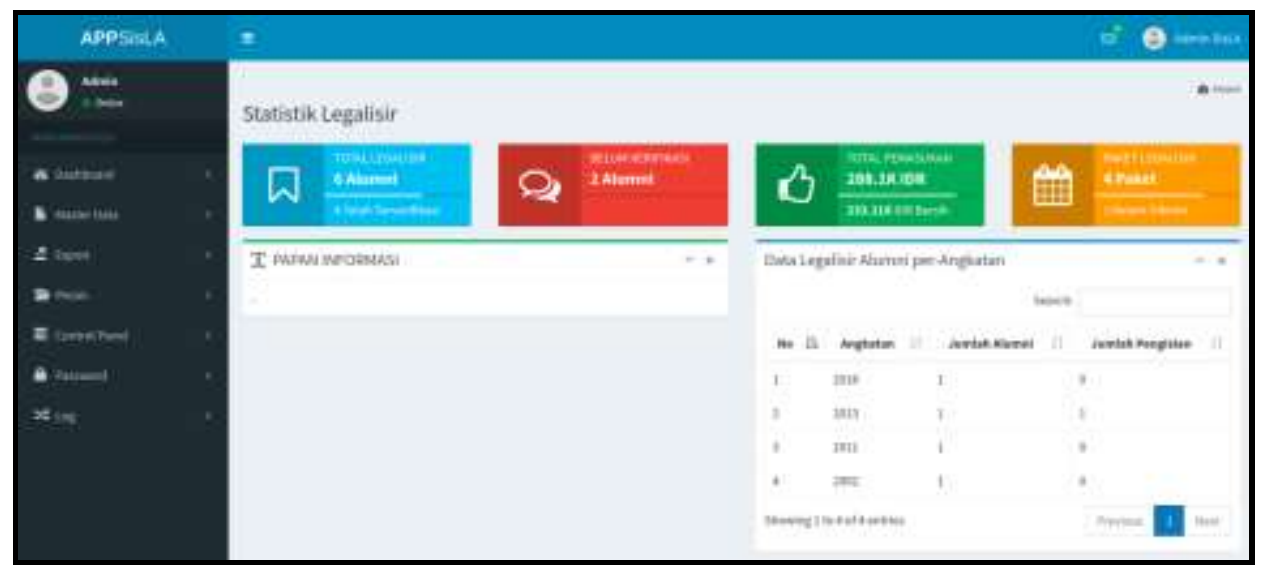

Fig. 8 Dashboard system

Telegram bot interface, as shown in Fig. 9. Some features of the telegram bot interface can be accessed with the keyword "/ help." The features are shown in Table I.

The features of the telegram bot are adjusted to the results of the observation of user needs. Telegram bot is an integration of the telegram API with a web-based information system that uses the Webhook method. This method does not overload the webserver. The bot method will make it easier for users to access information system search studies [7]. The bot model is based on the chat-bot with the interaction of the basic command "/"; the example is in Fig. 9 [22].

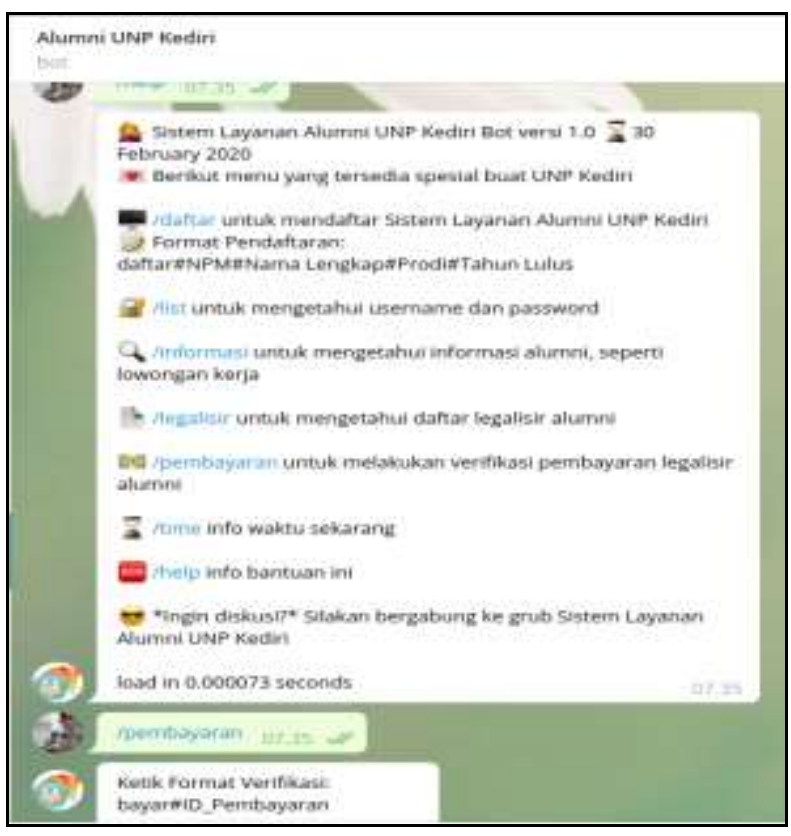

Fig. 9 Interface bot telegram
The business process interface of legalizing is in Fig. 10. This process integrates the shipping cost API with a web-based information system. On this system, the user can legalize with the condition that they have uploaded the file first. File uploaded in PDF format. Users can legalize and interact with the telegram bot to try out the features in Table I.

The Legalization process is carried out by filling out the legalized shipping data. Essential data are shown in Fig. 10, namely the data recipient's name file, delivery destination, specific delivery address details, and cell phone number. The target of the shipment uses the Shipping Cost API integration, so the nominal shipping costs will appear as shown in Fig. 11.

TABLE I

LEGALIZING BOT FITUR

\begin{tabular}{ll}
\hline \multicolumn{1}{c}{ Command } & \multicolumn{1}{c}{ Function } \\
\hline /daftar & $\begin{array}{l}\text { To register for the Alumni Service } \\
\text { System. } \\
\text { Registration format: } \\
\text { daftar\#NPM\#Name\#Department\#Gra } \\
\text { duation Year }\end{array}$ \\
/list & To know username and nassword \\
/informasi & To know alumni information such as iob \\
/legalisir & To know alumni legalizing list \\
/nembavaran & To verifv alumni's legalizing vavment \\
/time & Current time information \\
/heln & Svstem heln information \\
\hline
\end{tabular}




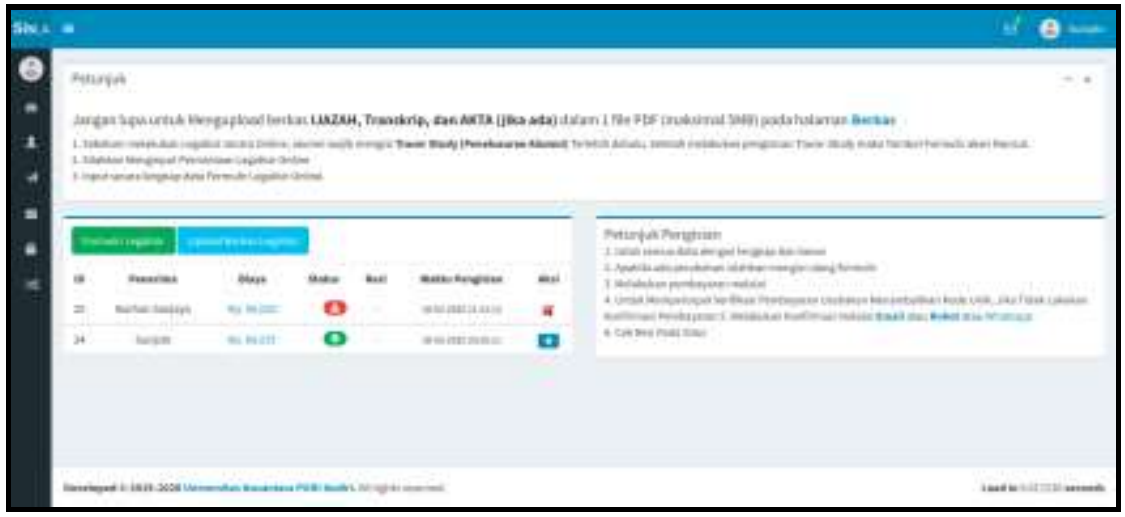

Fig. 10 Interface user legalization

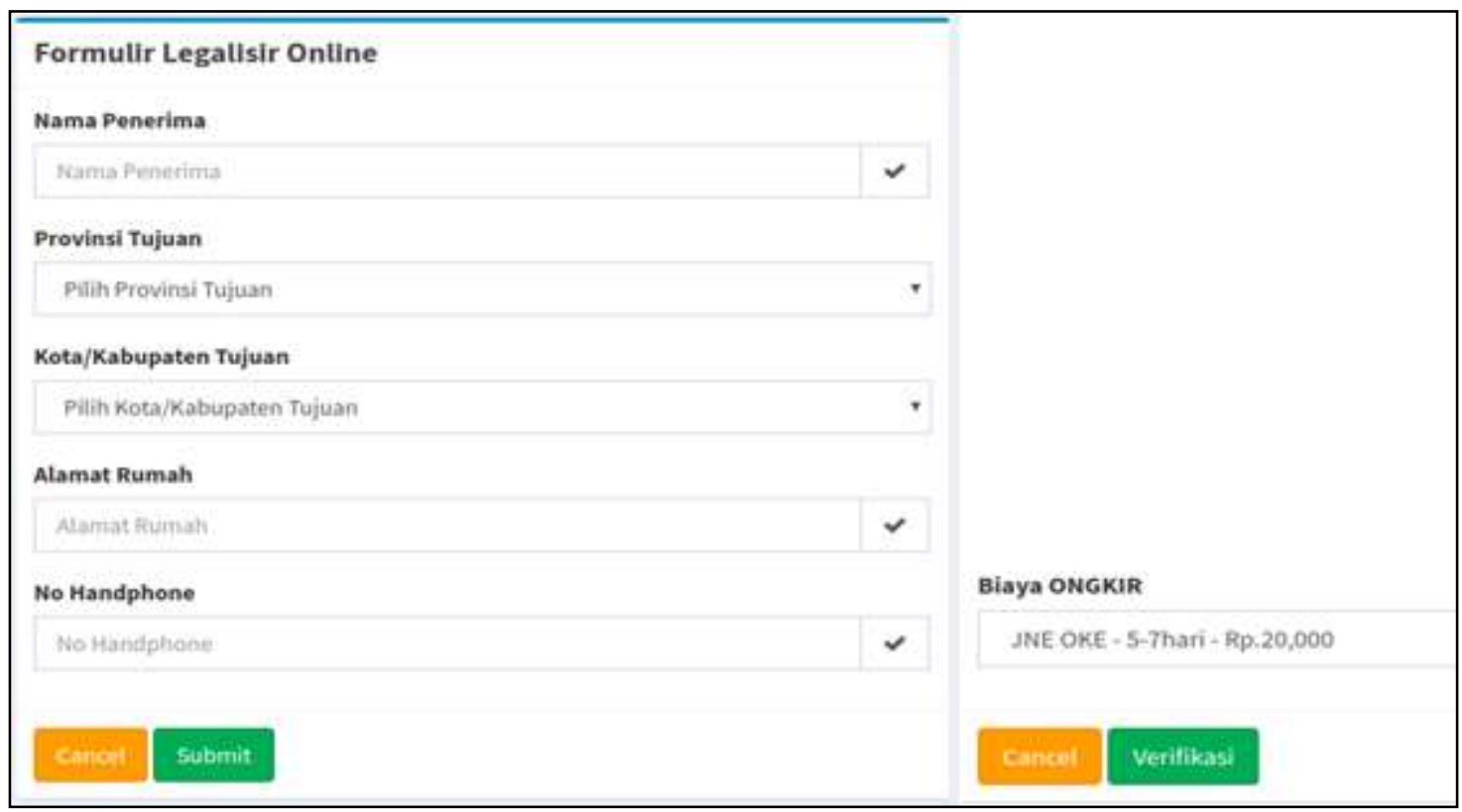

Fig. 11 Legalization business process

The last stage is Deployment. This stage is done by distributing application tests to several questioner samples. The amount of testing data is 60 respondents. The results of testing the legalization of the prototype information system legalization indicate that all functions are running well. The function results use the Black-Box testing method following the stages of communications and planning. Usability testing of the system uses the usability testing method for the level of effectiveness, efficiency, and satisfaction. The usability test results are shown in Fig. 12.

Usability testing at the level of efficiency is the lowest. An influencing factor is that some respondents are not yet familiar with Telegram Bot. Results Testing effectiveness, and satisfaction has good results. It is influenced by the information obtained very easy for respondents. The overall results of testing Fig. 12 show that the application can be used well and has excellent satisfaction. Usability value of 4.56 on a scale of 5 which shows that users can accept the information system usability test.

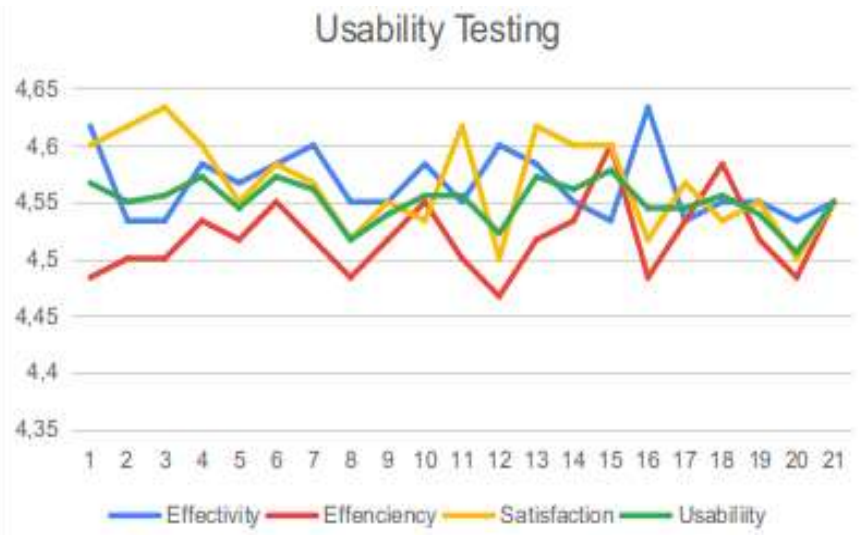

Fig. 12 Usability testing 


\section{CONCLUSION}

Testing in this study uses the Usability testing method. Usability testing uses three variables, namely, effectiveness, efficiency, and trustworthiness. Usability testing is used to determine modules and integration of built APIs, both based on user needs. User needs are the key to the success of a recipient's information system. Based on the usability test results obtained a value of 4.56 on a scale of 5 , which shows that users can receive information system usability tests. There is an essential note that efficiency performance is still lacking compared to other assessments. Lack of efficiency performance shows that the familiarity of the user side with the Telegram Social Messaging API. However, the effectiveness of API integration makes users comfortable using this information system. The results obtained from this study that the implementation of API integration in the approved system can run well and have a response in usability testing with a value of 4.56 on a scale of 5 .

\section{ACKNOWLEDGMENT}

The author would like to thank the Directorate of Research and Community Service (DRPM) of the Indonesian Ministry of Research and Technology, who has provided financial support for this research through a beginner lecturer research scheme (PDP).

\section{REFERENCES}

[1] R. Ibrahim and R. Ibrahim, "PENDIDIKAN MULTIKULTURAL: Pengertian, Prinsip, dan Relevansinya dengan Tujuan Pendidikan Islam," ADDIN, vol. 7, no. 1, Nov. 2015.

[2] T. Hendratmoko, D. Kuswandi, and P. Setyosari, "TUJUAN PEMBELAJARAN BERLANDASKAN KONSEP PENDIDIKAN JIWA MERDEKA KI HAJAR DEWANTARA," JINOTEP (Jurnal Inov. dan Teknol. Pembelajaran) Kaji. dan Ris. Dalam Teknol. Pembelajaran, vol. 3, no. 2, pp. 152-157, Jan. 2018.

[3] M. Reddy, API Design for C++. Elsevier, 2011.

[4] S. Ericko Surya, L. P. Dewi, and S. Rostianingsih, "Perancangan dan Pembuatan Website E-Commerce Mulia Kencana Motor," Aug. 2015.

[5] R. Nufusula and A. Susanto, "Rancang Bangun Chat Bot Pada Server Pulsa Mengunakan Telegram Bot API," JOINS (Journal Inf. Syst., vol. 3, no. 1, pp. 80-88, Jul. 2018.

[6] K. Fitri, Z. Zulhendra, and D. Kurniadi, "PERANCANGAN SISTEM INFORMASI LEGALISIR DOKUMEN BERBASIS WEB DI FAKULTAS TEKNIK UNIVERSITAS NEGERI
PADANG,"VoteTEKNIKA J. Vocat. Tek. Elektron. dan Inform., vol. 2, no. 2, Nov. 2018.

[7] S. Sucipto, N. C. Resti, T. Andriyanto, J. Karaman, and R. S. Qamaria, "Transactional database design information system web-based tracer study integrated telegram bot," in Journal of Physics: Conference Series, 2019, vol. 1381, no. 1, p. 12008.

[8] S. Sucipto, E. K. Dewi, N. C. Resti, and I. H. Santi, "Improving The Performance of Alumni Achievement Assessment by Integrating Website-Based Tracer Study Information Systems and Telegram API," TEKNIK, vol. 41, no. 1, pp. 72-77, May 2020.

[9] L. Banica, C. Stefan, I. Nedea, E. Soare, and others, "Softwarization Of The Production: The Industry 4.0 Approach," Sci. Bull. Sci., vol. 18, no. 1, pp. 23-30, 2019.

[10] A. M. Abubakar, H. Elrehail, M. A. Alatailat, and A. Elçi, "Knowledge management, decision-making style and organizational performance," J. Innov. Knowl., vol. 4, no. 2, pp. 104-114, 2019.

[11] N. Kock, D. Avison, and J. Malaurent, "Special Issue on Action Research in Information Systems," J. Manag. Inf. Syst., vol. 32, no. 3, pp. 630-632, 2017.

[12] N. Hidayati and S. Sismadi, "Application of Waterfall Model In Development of Work Training Acceptance System," INTENSIF J. Ilm. Penelit. dan Penerapan Teknol. Sist. Inf., vol. 4, no. 1, pp. 75-89, Feb. 2020.

[13] R. S. Pressman, Software Enggineering: A Practitioner's Approach (7th Edition). New York: McGraw-Hill, 2010.

[14] T. M. Cajita, D. I. Campos, G. Villapando, L. Gutierrez, and J. Taeza, "Reintroducing Aliguyon Using Vogler's Adaptation of the Monomyth Through a Game Development," IAFOR J. Arts Humanit., vol. 6, no. 1, pp. 87-108, Jun. 2019.

[15] M. Samadi Gharajeh, "Waterative Model: an Integration of the Waterfall and Iterative Software Development Paradigms," Database Syst. J., vol. X, pp. 75-81, 2019.

[16] C. Erlinger, "Instant-Messenger Bots als alternative Suchoberfläche," Informationspraxis, vol. 5, no. 1, 2019.

[17] V. V Vasilkova, N. I. Legostaeva, and E. A. Penkova, "Use of Chatbots in Volunteering," ДИСКУРС, vol. 5, no. 4, p. 87, 2019.

[18] B. N. Prastowo, N. A. S. Putro, and O. A. Dhewa, "PLO User Interface based on Telegram Bot," IJCCS (Indonesian J. Comput. Cybern. Syst., vol. 13, no. 1, p. 21, Jan. 2019.

[19] S. Sucipto, F. B. Hariawan, V. Nurita, and A. G. Tammam, "Functional Database in Gateway-based Price Service System [Basis Data Fungsional dalam Sistem Pelayanan Harga berbasis Gateway]," Bul. Pos dan Telekomun., vol. 16, no. 2, p. 101, Dec. 2018.

[20] S. Sucipto, "Perancangan Active Database System pada 
Sistem Informasi Pelayanan Harga Pasar," $J$. INTENSIF, vol. 1, no. 1, pp. 37-45, 2017.

[21] Sucipto, R. Indriati, and F. B. Hariawaan, "DESAIN DATABASE UNTUK OPTIMALISASI SISTEM PREDIKSI TRANSAKSI PENJUALAN," JIPI (Jurnal
Ilm. Penelit. dan Pembelajaran Inform., vol. 2, no. 2, pp. 88-93, 2017.

[22] K. V Wadanka, R. Y. Waghulde, and U. Taru, "Chatbot: An Application of AI," Int. J. Res. Eng. Sci. Manag., vol. 1, no. 9, pp. 139-141, 2018. 
JUITA: Jurnal Informatika e-ISSN: 2579-8901; Volume 8, Nomor 2, November 2020 